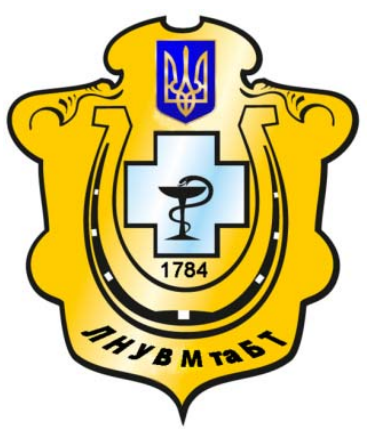

Науковий вісник Львівського національного університету ветеринарної медицини та біотехнологій імені С.3. Гжицького

Scientific Messenger of Lviv National University of Veterinary Medicine and Biotechnologies named after S.Z. Gzhytskyj

doi:10.15421/nvlvet6625

ISSN 2413-5550 print

ISSN 2518-1327 online

http://nvlvet.com.ua/

УДК 619:616-022.7:636.082.35

\title{
Гістологічні зміни в телят за гострого перебігу сальмонельозу
}

\author{
В.В. Лісова ${ }^{1}$, Г. Павленко ${ }^{1}$, Н.М. Романенко ${ }^{2}$ \\ lisovav@ukr.net \\ ${ }^{1}$ Національний університет біоресурсів і природокористування України, \\ вул. Героїв Оборони, 11, м. Київ, 03041, Украӥна \\ ${ }^{2}$ ВП НУБіП України Немішаєвський агротехнічний коледж, \\ вул. Технікумівська 4. смт. Немімаєве-1, Бородянський р-н. Київька обл. 07854, Украӥна
}

\begin{abstract}
Представлено результати вивчення гістологічних змін в телят віком 20 - 40 діб за гострого перебігу сальмонельозної інфекиії. При проведенні гістологічного дослідження, найбільш виразні зміни реєстрували в печіниі, тонкому відділі кимечнику і лімфоїдни органах, що зумовлено розмноженням тут збудника інфекиії. Характерними гістологічними змінами за гострого перебігу сальмонельозної інфекиії в телят даної вікової групи можна вважати: субміліарні інтралобулярні коагуляційні ареактивні некрози в печінці; клітинні гранульоми в печінці; гострий дифузний серозно-катаральний ентерит $з$ геморагічним ухилом; серозний лімфаденіт мезентеріальних лімфатичних вузлів; гострий катаральний абомазит. Також неспециффічними, але постійними морфологічними ознаками хвороби є гіперплазія лімфоїдних утворень слизової оболонки тонкого відділу кишечнику, мезентеріальних лімфовузлів, селезінки і дистрофічні зміни паренхіматозних органів.

Проведено аналіз і теоретичне обтрунтування патогенетичних механізмів виявлених мікроструктурних змін. Показано, що в патогенезі сальмонельозу важливу роль відіграють бактеріємія і токсемія, які призводять до ураження ендотелію судин, формених елементів крові з наступним порушенням механізмів гемостазу і розвитком інфекиійно-токсичного шоку.

Ключові слова: телята, сальмонельоз, гістологічні зміни, печінка, клітинні гранульоми, некрози, серозно-катаральний ентерит, гіперплазія лімфоїдних органів, дистрофічні зміни.
\end{abstract}

\section{Гистологические изменения у телят при остром течении сальмонеллеза}

\author{
В.В. Лисовая ${ }^{1}$, А. Павленко ${ }^{1}$, Н.М. Романенко ${ }^{2}$ \\ lisovav@ukr.net
}

Национальньій университет биоресурсов и природопользования Украиньл,

ул. Героев Обороны, 11, Киев, 03041, Украина

ОП НУБиП Украины Немешаевский агротехнический колледж,

ул. Техникумовская 4. с. Немешаево-1, Бородянский р-н. Киевская обл. 07854, Украина

\begin{abstract}
Представлены результаты изучения гистологических изменений у телят возрастом 20 - 40 суток при остром течении сальмонеллезной инфекиии. При проведении гистологического исследования, наиболее выраженные изменения регистрировали в печени, тонком отделе кишечника и лимфоидных органах, что обусловлено размножением здесь возбудителя инфекичи. Характерными гистологическими изменениями при остром течении сальмонеллезной инфекции у телят данной возрастной группы можно считать: субмиллиарные интралобулярные коагуляиионные ареактивные некрозы в печени; клеточные гранулемы в печени; острый диффузный серозно-катаральный энтерит с геморрагическим уклоном; серозный лимфаденит мезентериальных лимфатических узлов; острый катаральный абомазит. Также неспецифическими, но постоянными морфологическими признаками болезни являются гиперплазия лимфоидных образований слизистой оболочки тонкого отдела кишечника, мезентериальных лимфоузлов, селезенки и дистрофические изменения паренхиматозных органов.
\end{abstract}

Citation:

Lisova, V., Pavlenko, A., Romanenko, N. (2016). Histological changes in calves at acute salmonellosis. Scientific Messenger LNUVMBT named after S.Z. Gzhytskyj, 18, 2(66), 122-125. 
Проведен анализ и теоретическое обоснование патогенетических механизмов выявленных микроструктурных изменений. Показано, что в патогенезе сальмонеллеза важную роль играют бактериемия и токсемия, которые приводят к поражению эндотелия сосудов, форменных элементов крови с последующзи нарушением механизмов гемостаза и развитием инфекиионно-токсического иока.

Ключевые слова: телята, сальмонеллез, гистологические изменения, печень, клеточные гранулемы, некрозы, серознокатаральный энтерит, гиперплазия лимфоидных органов, дистрофические изменения.

\title{
Histological changes in calves at acute salmonellosis
}

\author{
V. Lisova ${ }^{1}$, A. Pavlenko ${ }^{1}$, N. Romanenko ${ }^{2}$ \\ lisovav@ukr.net \\ ${ }^{I}$ National University of life and environmental sciences of Ukraine, \\ Heroyiv Oborony Str., 11, Kyiv, 03041, Ukraine; \\ ${ }^{2}$ Nemishayevskyy Agricultural College, \\ Tehnikumivska Str., 4, Nemishaevo-1, 07854, Ukraine
}

The results of study of histological changes in calves by age of $20-40$ days at acute salmonellosis infection are presented. At a histological research the most expressed changes were registered in the liver, thin intestine and lymphoid organs that contingently reproduction here of the causative agent. At acute form of salmonellosis in calves of this age-grade characteristic histological changes include: submilliar, intralobular, coagulativ, areactive foci of necrosis in a liver; cell granuloma in a liver; the acute diffusive serous-catarrhal enteritis with a hemorrhagic accent; serous lymphadenitis of intestinal lymph nodes; the acute diffusive catarrhal abomasitis. Also nonspecific, but constant morphological signs of salmonellosis are hyperplasia Peyer's patches of a small intestine, intestinal lymph nodes, spleen and dystrophic changes of parenchymal organs.

An analysis and theoretical ground of pathogenetic mechanisms of the educed microstructural changes are conducted. It is shown that in pathogenesis of salmonellosis an important role is played bacteriaemia and toxinaemia, which result to the defeat of endothelia of vessels and blood cells with subsequent violation of mechanisms of haemostasis zand development of the infectiouslytoxic shock.

Key words: calves, salmonellosis, histological changes, liver, cell granuloma, necrosis, serous-catarrhal enteritis, hyperplasia of lymphoid organs, dystrophic changes.

\section{Вступ}

Як показує практика ведення тваринницької галузі, значні збитки галузі наносять шлунковокишкові хвороби інфекційної етіології (Dyka and Ivchenko, 1999). За останні роки у багатьох країнах світу відзначено значне зростання кількості спалахів захворювання сальмонельозом як сільськогосподарських тварин, так і людей. Рівень захворювання людей на сальмонельоз в Україні в останні роки не зменшується: на 100000 населення в ці роки він коливався в межах величин 15,91 - 21,78 випадків (Pundyak, 2013).

Відомо, що серед інших зоонозів сальмонельоз не має собі рівних за складністю епідеміології і труднощів боротьби $з$ ним. До цих пір він залишається світовою проблемою, зоонозом, який є лідером харчових токсикоінфекцій людини в більшості країн і відноситься до небагатьох бактеріальних кишкових інфекцій, при яких захворюваність не має тенденції до зниження, в тому числі у високорозвинутих країнах (Patrick et al., 1999; Madison, 2006; Dvorskaya and Fotina, 2009; Kurtyak and Pundyak, 2014).

Дані досліджень Салімова (2005), свідчать про високу достовірність саме клініко-морфологічного напряму діагностики хвороб у науково-практичній діяльності ветеринарних спеціалістів при перших випадках загибелі тварин, а також забитих 3 діагностичною метою, виходячи з вчення про патоморфоз єдиної системи біологічного комплексу мати-плідновонароджений (Salimov, 2005).
Отже, на даному етапі метою нашої роботи було провести патогістологічне дослідження органів і тканин телят віком 20 - 40 діб за гострого перебігу сальмонельозу. Тому для досягнення мети були поставлені завдання:

- виготовити і пофарбувати гістологічні зрізи 3 відібраного під час розтину патологічного матеріалу;

- дослідити, описати i проаналізувати мікроскопічні зміни в органах $\mathrm{i}$ тканинах за сальмонельозу.

\section{Матеріал і методи досліджень}

Матеріалом дослідження слугували шматочки органів і тканин відібраних під час розтину 5 трупів телят віком 20 - 40 діб, які загинули протягом 5-7 діб 3 моменту появи перших клінічних ознак хвороби. Патологічний матеріал фіксували в 10\% - вому водному розчині нейтрального формаліну й заливали в парафін. Виготовлені гістозрізи фарбували гематоксиліном Караці й еозином за стандартними прописами (Goralskij et al., 2011). Мікроструктурні зміни в гістопрепаратах досліджували під світловим мікроскопом MC 100LED (Micros Austria) при збільшеннях від 70 до 1000.

\section{Результати та їх обговорення}

При проведенні гістологічного дослідження виявляли ознаки гострого катару в сичузі й тонкому відділі кишечника, зокрема в порожній кишці. Морфологі- 
чним проявом гострого катару були запальна гіперемія судин підслизової основи і їі набряк внаслідок серозного просочення, гіперплазія і гіпертрофія келихоподібних клітин в епітелії ворсинок слизової оболонки. У дистальній частині порожньої кишки виявляли гіперплазовані одинокі й скупчені лімфоїдні вузлики кишкової стінки. Такі вузлики мали вигляд округлих утворень інтенсивного синього кольору, що являють собою скупчення великої кількості активних лімфоцитів. Інколи виявляли невеликі дифузні осередки геморагій в підслизовій основі, переважно навколо венозних судин і дрібні ерозії слизової оболонки у вигляді осередків відшарування пластів епітелію i гіперемії судин мікроциркуляції.

При мікроскопічному дослідженні печінки відмічали розширення і переповнення кров'ю синусоїдних капілярів, особливо в центрі часточок, деструкцію балкової структури печінки i, як наслідок, хаотичне розташування гепатоцитів. Формені елементи крові, переважно еритроцити, в просвітах судин тріад i центральних вен мали вигляд безструктурних еозинофільних мас. Спостерігали зернисту дистрофію гепатоцитів, яка морфологічно проявлялася набуханням клітин, зникненням прозорості цитоплазми, появою еозинофільної зернистості білкової природи, що виникає в результаті коагуляції білкових молекул. Ядра таких гепатоцитів були збільшені, не чітко оконтуровані або взагалі відсутні. У окремих випадках виявляли ділянки жирової дистрофії з утворенням характерних вакуолей різних розмірів у цитоплазмі й зміщенням ядра до периферії - 3 утворенням перснеподібних клітин.

Майже в кожній печінковій часточці знаходили декілька характерних клітинних вузликів або гранульом, які являли щільне скупчення клітинних елементів: лімфоцитів з великим чітко контурованим ядром і вузьким обідком цитоплазми, макрофагів неправильної форми з великим об'ємом цитоплазми, нейтрофільних лейкоцитів з бобоподібними ядрами і поодиноких плазматичних клітин $з$ ексцентрично розташованим ядром і великим об'ємом цитоплазми.

Одночасно 3 клітинними вузликами в печінкових часточках реєстрували субміліарні фокуси інтралобулярних коагуляційних некрозів, які мали ареактивний характер. У центрі таких осередків виявляли еозинофільний клітинний детрит, а на периферії - проліферацію макрофагів неправильної форми з великим об'ємом цитоплазми і гепатоцити в стані некробіозу, який морфологічно проявлявся каріорексисом i каріолізисом. Цитоплазма таких гепатоцитів бліда, чіткі контури клітин відсутні.

У селезінці й мезентеріальних лімфатичних вузлах виявляли гіперплазію лімфоїдних вузликів внаслідок проліферації клітин лімфоїдного ряду. Інколи траплялися дрібні фокуси некрозів.

Отже, первинне місце локалізації сальмонел шлунково-кишковий тракт, де відбувається розмноження збудника, який потім потрапляє до лімфоїдних утворень кишечника і брижі, після чого проникає в кровоносне русло. Саме в ньому починається низка процесів, які обумовлюють подальший розвиток па- тологічних змін, як в окремих органах, так і цілому організмі.

Відомо, що ендотелій судин уражується як самим збудником, так і токсичними речовинами, що утворюються в процесі їх життєдіяльності. Чималу роль в пошкодженні стінок судин відіграють циркулюючі в крові імунні комплекси, рівень яких підвищується за бактеріальних і вірусних інфекцій. Крім того, відома гемолітична дія бактерій і вірусів, які безпосередньо взаємодіють 3 еритроцитами. Порушення мікроциркуляції зумовлює гіпоксію в тканинах і $є$ провідним чинником в патогенезі виявлених в печінці дисциркуляторних дистрофій. А наявність субміліарних ареактивних некрозів $є$ морфологічною ознакою прогресування ацидозу і деструкції клітинних структур органу. Отже, виявлені в печінці зміни можна вважати морфологічним еквівалентом інфекційно - токсичного, тобто бактеріального шоку.

Таким чином, при проведенні патоморфологічного дослідження, найбільш виразні зміни реєстрували в тонкому відділі кишечнику, печінці й лімфоїдних органах, що зумовлено саме розмноженням в цих органах збудника інфекції.

\section{Висновки}

Морфологічні критерії на яких базується патоморфологічний діагноз за гострого перебігу сальмонельозу в телят віком 20 - 40 діб включають: субміліарні інтралобулярні коагуляційні ареактивні некрози в печінці; клітинні гранульоми в печінці; гострий дифузний серозно-катаральний ентерит 3 геморагічним ухилом; гострий катаральний абомазит; серозний лімфаденіт мезентеріальних лімфатичних вузлів. Постійними неспецифічними морфологічними ознаками $€$ : гіперплазія одиноких і скупчених лімфоїдних вузликів тонкого відділу кишечнику, мезентеріальних лімфовузлів і селезінки; дистрофічні зміни паренхіматозних органів.

Перспективи подальших досліджень. 3 метою повного охоплення патоморфологічної картини хвороби в даної вікової групи телят, наступним етапом доцільно провести вивчення морфологічних особливостей за даної патології з використанням гістохімічних методів дослідження.

\section{Бібліографічні посилання}

Dyka, O.V., Ivchenko, V.M. (1999). Epizootychna sytuaciya shodo salmonelozu telyat v Ukraini [Epizootic situation on calves salmonellosis in Ukraine]. Visnyk Bilocerkivskogo derzhavnogo agrarnogo universytetu - Bulletin of Bila Cerkva State Agrarian University. 9, 68-74 (in Ukrainian).

Pundyak, T.O. (2013) Dynamika antytil za spontannogo salmonelozu u telyat [Dynamics of antibodies spontaneous salmonella calves]. The Animal Biology, 15, 4, 106-111 (in Ukrainian).

Madison V. (2006). Nebezpeka velykogo stada: salmoneloz [Danger of great herd: salmonellosis ]. Agrosektor, 3, 30-31 (in Ukrainian). 
Kurtyak, B.M., Pundyak, T.O. (2014). Rezultaty kompleksnogo doslidzhennya koriv $\mathrm{z}$ metoyu vyyavlennya salmonelonosiystva u neblagopoluchnykh shodo salmonelozu gospodarstvakh [Results of a comprehensive study of cows salmonelonosiystva to detect salmonella in disadvantaged on farms ]. Scientific Journal of National University of Veterinary Medicine and Biotechnologies named after S. Z. Gzhytsky, 16, 2(59), 1, 138146 (in Ukrainian).

Patrick, L., McDonough, David, Fogelman, Sang, J., Shin, Michael, A., Brunner, Donald, H., Lein. (1999). Salmonella enterica Serotype Dublin Infection: an Emerging Infectious Disease for the Northeastern United States. Journal of Clinical Microbiology, 37(8), 2418-2427.
Dvorskaya, Ju.E., Fotina, T.I. (2009). Salmonella: privychnaya problema, novye resheniya [Salmonella: a familiar problem, new solutions]. Effective stock raising, 3, 42-45 (in Russian).

Salimov, V.A. (2005). Patomorfologiya i differentsialnaya diagnostika bakterialnykh faktornykh boleznei porosyat $\mathrm{i}$ telyat [Pathomorphology and differential diagnostics of bacterial factorial disease of pigs and calves]. Samara, 40 (in Russian).

Goralskij L.P., Homych V.T., Kononskij O.I. (2011). Osnovy histologichnoyi tehniky i morfofunkcionalni metody doslidjen u normi ta pry patologiyi [Foundations of histological engineering and morphofunctional methods of research in norm and pathology]. Jytomir, Ukrainian: Polissya (in Ukrainian).

Стаття надійшла до редакиії 28.09.2016 